\title{
Commentary: Extracellular peptidase hunting for improvement of protein production in plant cells and roots
}

\author{
Karl J. Kunert * and Priyen Pillay \\ Molecular Plant Physiology Group, Plant Science Department, Forestry and Agricultural Biotechnology Institute, University of \\ Pretoria, Pretoria, South Africa
}

Keywords: proteases, recombinant protein production, protein stability, in silico analysis, molecular pharming

\section{A commentary on}

Extracellular peptidase hunting for improvement of protein production in plant cells and roots by Lallemand, J., Bouché, F., Desiron, C., Stautemas, J., de Lemos Esteves, F., Périlleux, C., et al. (2015). Front. Plant Sci. 6:37. doi: 10.3389/fpls.2015.00037

Despite much recent success in plant-based protein production, key challenges, such as undesired plant proteolytic activities, still severely compromises current recombinant protein production with peptidases affecting protein stability (Pillay et al., 2013). The paper by Lallemand et al. (2015) reporting about identification of extracellular peptidases compromising protein production in plant cells and roots is therefore an excellent contribution to ultimately advance our understanding of peptidase action in plant-based recombinant protein production (Lallemand et al., 2015).

OPEN ACCESS

Edited by:

Kazuhito Fujiyama,

Osaka University, Japan

Reviewed by:

Stefan Schillberg,

Fraunhofer IME, Germany

*Correspondence:

Karl J. Kunert,

karl.kunert@up.ac.za

Specialty section:

This article was submitted to

Plant Biotechnology,

a section of the journal

Frontiers in Plant Science

Received: 11 May 2015

Accepted: 07 July 2015

Published: 21 July 2015

Citation:

Kunert KJ and Pillay P (2015)

Commentary: Extracellular peptidase hunting for improvement of protein production in plant cells and roots.

Front. Plant Sci. 6:557.

doi: 10.3389/fpls.2015.00557
Since research has so far not paid a great amount of attention to this problem, a more detailed view, as taken in the paper, is highly beneficial to elucidate such peptidases in the extracellular space. This offers great benefits in terms of protein stability and higher protein production yield.

Previous approaches used to address this challenge in plants has for example included peptidase silencing by applying RNA interference technology (Voinnet et al., 2003; Hatsugai et al., 2004) and also co-expressing specific protease inhibitors as "companions" to limit specific protease activities (Goulet et al., 2010, 2012; Pillay et al., 2012). However, silencing a specific peptidase or co-expressing a "companion" protease inhibitor always bears the risk of vital plant metabolic pathways also being affected (Van der Vyver et al., 2003; Senthil-Kumar et al., 2007). This can compromise efficient recombinant protein production in a plant-based system. In addition, work on Arabidopsis, as already done by Lallemand et al. (2015), with its existing wealth of transcriptome and gene data (The_Arabidopsis_Genome_Initiative, 2000) will enable future identification of similar peptidases in other plant species when comparative genomics approaches are applied in combination with Next Generation Sequencing.

By investigating two plant species (Arabidopsis thaliana and Nicotiana tabacum); the Lallemand et al. (2015) study particularly unraveled that root-secretion production contained more peptidase activity than, for example, the extracellular medium of cell suspensions. A less proteolytic enriched environment is certainly more favorable for the production of recombinant proteins, especially antibodies. This key finding has, therefore, not only significantly extended our understanding how particular plant species contribute to proteolytic activity and type of peptidase produced but has also contributed to advancing our understanding on how proteases in different plant parts can compromise recombinant protein stability. The study has whereby set a strong working basis for exploring, in the future, proteolytic action in greater depth. 


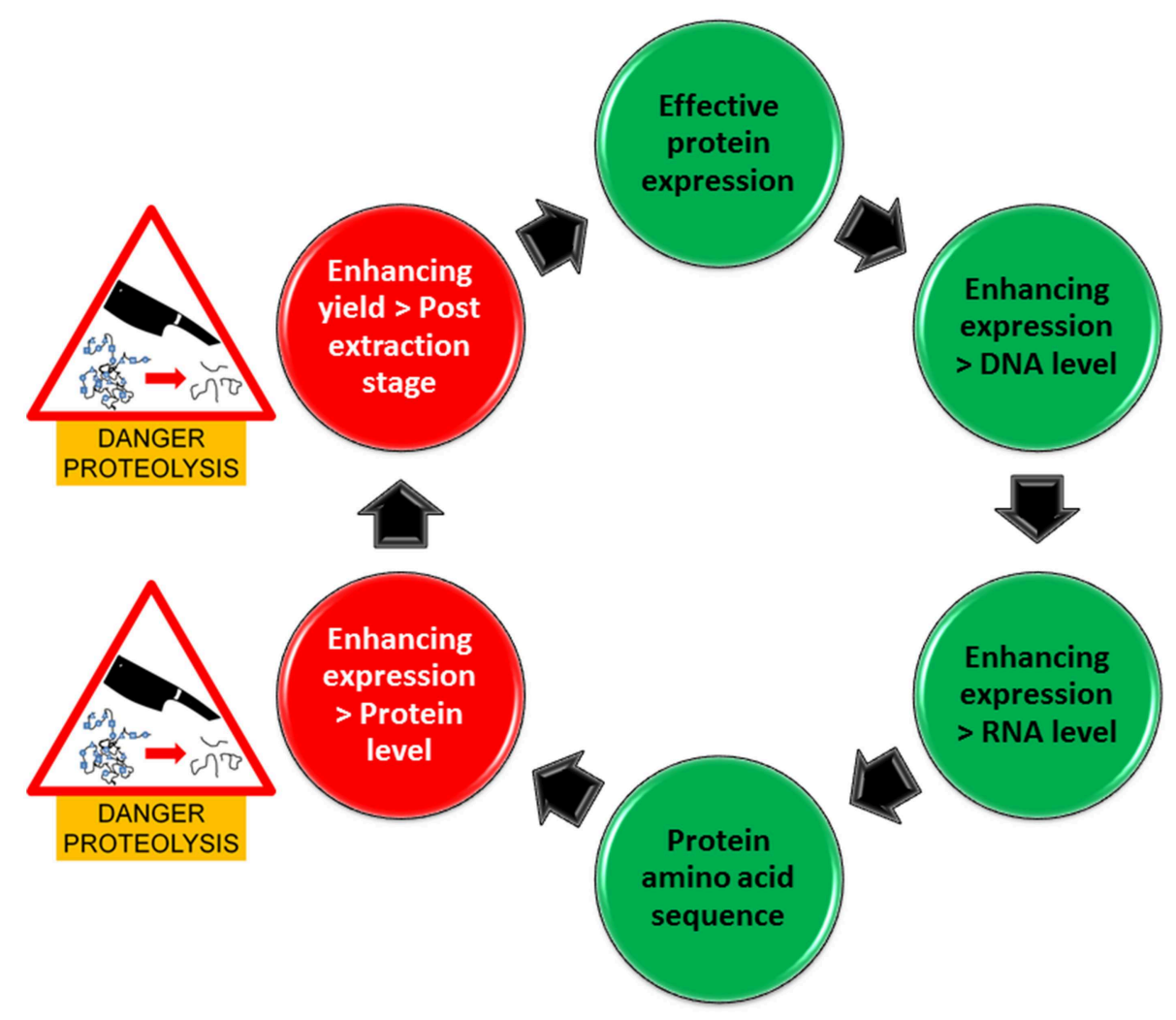

FIGURE 1 | Pipeline for enhancing protein production in expression systems. Green circles represent areas that are free of danger from proteolysis whilst red circles represent areas where there is a danger of proteolysis.

Lallemand et al. (2015) also focused on establishing genotranscriptome data. By also tapping into the wealth of existing peptidase data, Lallemand et al. (2015) further carried out an in-depth in silico analysis of existing Arabidopsis genome and transcriptome data. Remarkably, the search resulted in identification of serine and metallo-peptidases as main peptidases involved in proteolytic processes. These peptidases were consistently expressed in the two investigated production systems. By applying the approach of merging activity assays with geno-transcriptome data, specific Ser-peptidases, potentially responsible for target degradations, were identified. Lallemand et al. (2015) proposed that these peptidases should first be prime candidates for modification to improve protein stability.

Specific inhibition of Ser-proteases is certainly an attractive idea which is also supported by previous findings (Goulet et al., 2012). However, the question still remains, how many other proteases are there particularly in plants currently applied in recombinant protein production and what role(s) do they play in protein production and stability. For example commercial companies are primarily using Nicotiana benthamiana and also the unconventional method of producing proteins in carrot cells is applied. These plant species might have very different protease profiles. Investigating such systems for protein production from a plant-based perspective, suggests commercial preferences in industry which are excellent indicators for researchers to adopt in their methodology. Consequently, more definitive investigations are required in protease profiling with the option to avoid plant species with a specific profile unfavorable for the production of a specific recombinant protein. In this regard, recent Next generation sequencing and also proteomics approaches for protease profiling (Vandenabeele et al., 2003; van Wyk et al., 2014) will allow the identification of a great number of peptidases as well as the establishment of their particular expression profiles in plant species targeted for recombinant protein production. In addition, more focused assessments in recombinant protein susceptibility to proteases have to be carried out to identify potential cleavage sites within the protein. These considerations and risks are encapsulated in our pipeline for enhancing protein expression (Figure 1) which illustrates two stages where proteins are most vulnerable to proteolysis. A different complement of plant-derived proteases may be released during the extraction process from a cellular compartment that is different to that where the target protein is originally localized and thus may also co-purified during the purification process. Once the inherent susceptibility of the target protein is determined, appropriate inhibitors can be used to ameliorate the negative effects of proteases during extraction and purification. 
Without doubt, the study is, as Lallemand et al. (2015) have already outlined, an excellent starting point to develop new strategies for identifying proteolytic activity with the goal of enhancing recombinant protein stability.

\section{References}

Goulet, C., Benchabane, M., Anguenot, R., Brunelle, F., Khalf, M., and Michaud, D. (2010). A companion protease inhibitor for the protection of cytosoltargeted recombinant proteins in plants. Plant Biotechnol. J. 8, 142-154. doi: 10.1111/j.1467-7652.2009.00470.x

Goulet, C., Khalf, M., Sainsbury, F., D’Aoust, M. A., and Michaud, D. (2012). A protease activity-depleted environment for heterologous proteins migrating towards the leaf cell apoplast. Plant Biotechnol. J. 10, 83-94. doi: 10.1111/j.14677652.2011.00643.x

Hatsugai, N., Kuroyanagi, M., Yamada, K., Meshi, T., Tsuda, S., Kondo, M., et al. (2004). A plant vacuolar protease, VPE, mediates virus-induced hypersensitive cell death. Science 305, 855-858. doi: 10.1126/science.1099859

Lallemand, J., Bouché, F., Desiron, C., Stautemas, J., De Lemos Esteves, F., Périlleux, C., et al. (2015). Extracellular peptidase hunting for improvement of protein production in plant cells and roots. Front. Plant Sci. 6:37. doi: 10.3389/fpls.2015.00037

Pillay, P., Kibido, T., Plessis, M., Vyver, C., Beyene, G., Vorster, B. J., et al. (2012). Use of Transgenic Oryzacystatin-I-Expressing plants enhances recombinant protein production. Appl. Biochem. Biotechnol. 168, 1608-1620. doi: 10.1007/s12010-012-9882-6

Pillay, P., Schlüter, U., Van Wyk, S., Vorster, B., and Kunert, K. (2013). Proteolysis of recombinant proteins in bioengineered plant cells. Bioengineered 5, 1-6. doi: 10.4161/bioe. 25158

Senthil-Kumar, M., Hema, R., Anand, A., Kang, L., Udayakumar, M., and Mysore, K. S. (2007). A systematic study to determine the extent of gene silencing in Nicotiana benthamiana and other Solanaceae species when heterologous gene sequences are used for virus-induced gene silencing. New Phytol. 176, 782-791. doi: 10.1111/j.1469-8137.2007. 02225. $\mathrm{x}$

\section{Funding}

This work was supported by National Research Foundation (NRF) as NRF incentive funding to KK and a NRF bursary to PP.

The_Arabidopsis_Genome_Initiative (2000). Analysis of the genome sequence of the flowering plant Arabidopsis thaliana. Nature 408, 796-815. doi: $10.1038 / 35048692$

Van der Vyver, C., Schneidereit, J., Driscoll, S., Turner, J., Kunert, K., and Foyer, C. H. (2003). Oryzacystatin I expression in transformed tobacco produces a conditional growth phenotype and enhances chilling tolerance. Plant Biotechnol. J. 1, 101-112. doi: 10.1046/j.1467-7652.2003.00010.x

van Wyk, S. G., Du Plessis, M., Cullis, C. A., Kunert, K. J., and Vorster, B. J. (2014) Cysteine protease and cystatin expression and activity during soybean nodule development and senescence. BMC Plant Biol. 14:294. doi: 10.1186/s12870-0140294-3

Vandenabeele, S., Van Der Kelen, K., Dat, J., Gadjev, I., Boonefaes, T., Morsa, S., et al. (2003). A comprehensive analysis of hydrogen peroxide-induced gene expression in tobacco. Proc. Natl. Acad. Sci. U.S.A. 100, 16113-16118. doi: $10.1073 /$ pnas. 2136610100

Voinnet, O., Rivas, S., Mestre, P., and Baulcombe, D. (2003). An enhanced transient expression system in plants based on suppression of gene silencing by the p19 protein of tomato bushy stunt virus. Plant J. 33, 949-956. doi: 10.1046/j.1365-313X.2003.01676.x

Conflict of Interest Statement: The authors declare that the research was conducted in the absence of any commercial or financial relationships that could be construed as a potential conflict of interest.

Copyright (c) 2015 Kunert and Pillay. This is an open-access article distributed under the terms of the Creative Commons Attribution License (CC BY). The use, distribution or reproduction in other forums is permitted, provided the original author(s) or licensor are credited and that the original publication in this journal is cited, in accordance with accepted academic practice. No use, distribution or reproduction is permitted which does not comply with these terms. 